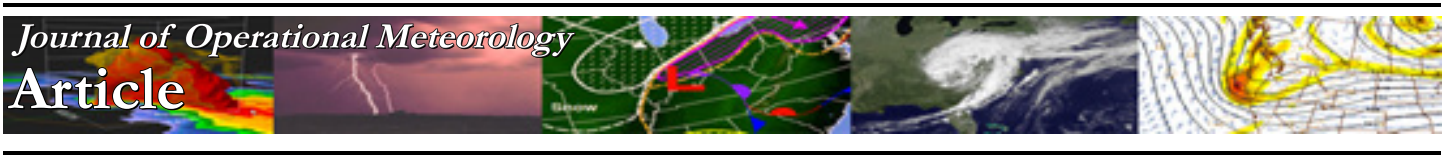

\title{
A Synoptic and Mesoscale Analysis of Heavy Rainfall at Portland, Maine, 13-14 August 2014
}

\author{
MARGARET B. CURTIS \\ NOAA/National Weather Service, Gray, ME
}

(Manuscript received 30 June 2016; review completed 15 December 2016)

\begin{abstract}
Portland, Maine, experienced record setting rainfall of $163.3 \mathrm{~mm}$ (6.43 in) on 13-14 August 2014, which resulted in urban flash flooding. This paper examines the key ingredients for heavy convective rainfall: high specific humidity, intense vertical motion, and long rainfall duration at both the synoptic scale and mesoscale. A favorable environment for flooding is identified from positive anomalies in the specific humidity and a synoptic scale, upper-level trough just upstream of Portland. The existence of a low-level jet altered the propagation of the responsible convective system as it approached Portland. This jet resulted in a change in the mesoscale beta convective element propagation vector $\left(V_{\mathrm{MBE}}\right)$. The concept of residence time as a function of the angle between the synoptic motion and $\mathrm{V}_{\mathrm{MBE}}$ is introduced and found to increase the duration of heavy rainfall in this case. In addition to the effects attributable to system motion, a coastal front (more commonly a winter phenomenon) is also identified in this case. This front enhanced the vertical motion, further increasing the local rainfall maximum over the Portland area.
\end{abstract}

\section{Introduction}

Heavy rainfall and flash flooding impacted the Portland, Maine, metro region on the evening of 13 August 2014. The total amount recorded was $163.3 \mathrm{~mm}$ (6.43 in). This set a new daily maximum rainfall record for 13 August and also ranked as the 5th greatest 24-hr rainfall at Portland. Furthermore, most of the rainfall, more than $101.6 \mathrm{~mm}$ (4 in), fell in just two hours.

This case was selected because of the historic nature of the rainfall. In addition to the flooding in Portland, Islip, New York, also set a 24-hr rainfall record for New York State several hours before rainfall began in Portland. In southern Maine, heavy precipitation occurred throughout the evening of 13 August 2014. Figure 1 shows the rainfall received across the region. Even though a large portion of southern Maine and New Hampshire received more than $50.8 \mathrm{~mm}$ (2 in) of rain, the highest amounts were focused in the Portland metro region where $152-203 \mathrm{~mm}(6-8$ in) fell. These very large rainfall amounts resulted in urban flash flooding and caused $\$ 1.5$ million in damage for the region (NCDC 2014).

The 24-hr rainfall record for Portland is $298.2 \mathrm{~mm}$
(11.74 in) (Menne et al. 2012). Even though the 13-14 August 2014 total rainfall was not record setting, the high rainfall rates resulted in widespread urban flooding. Figure 2 shows the rainfall recorded by the Automated Surface Observing Station (ASOS) at the Portland International Jetport (KPWM). The 1-min rainfall, 15min average rainfall rate, and total accumulation are plotted. Most of the rain fell between 0100 and 0300 UTC 14 August 2014 (9-11 pm EDT), and rainfall rates peaked at more than $110 \mathrm{~mm} \mathrm{hr}^{-1}\left(4.33 \mathrm{in} \mathrm{hr}^{-1}\right)$.

According to Doswell et al. (1996), the key ingredients for heavy precipitation are high rainfall rates and long rainfall duration. Variables important for producing high rainfall rates include precipitation efficiency (E), high specific humidity (q), and strong upward vertical motion (w) (Doswell et al. 1996). Rainfall duration is dependent on the motion of both the individual cells and the system as a whole. Rainfall is maximized when multiple cells within a cluster pass over the same location (Doswell et al. 1996). Jessup and Colucci (2012) examined mesoscale convective systems resulting in heavy rainfall in the Northeast United States and found back-building features are 


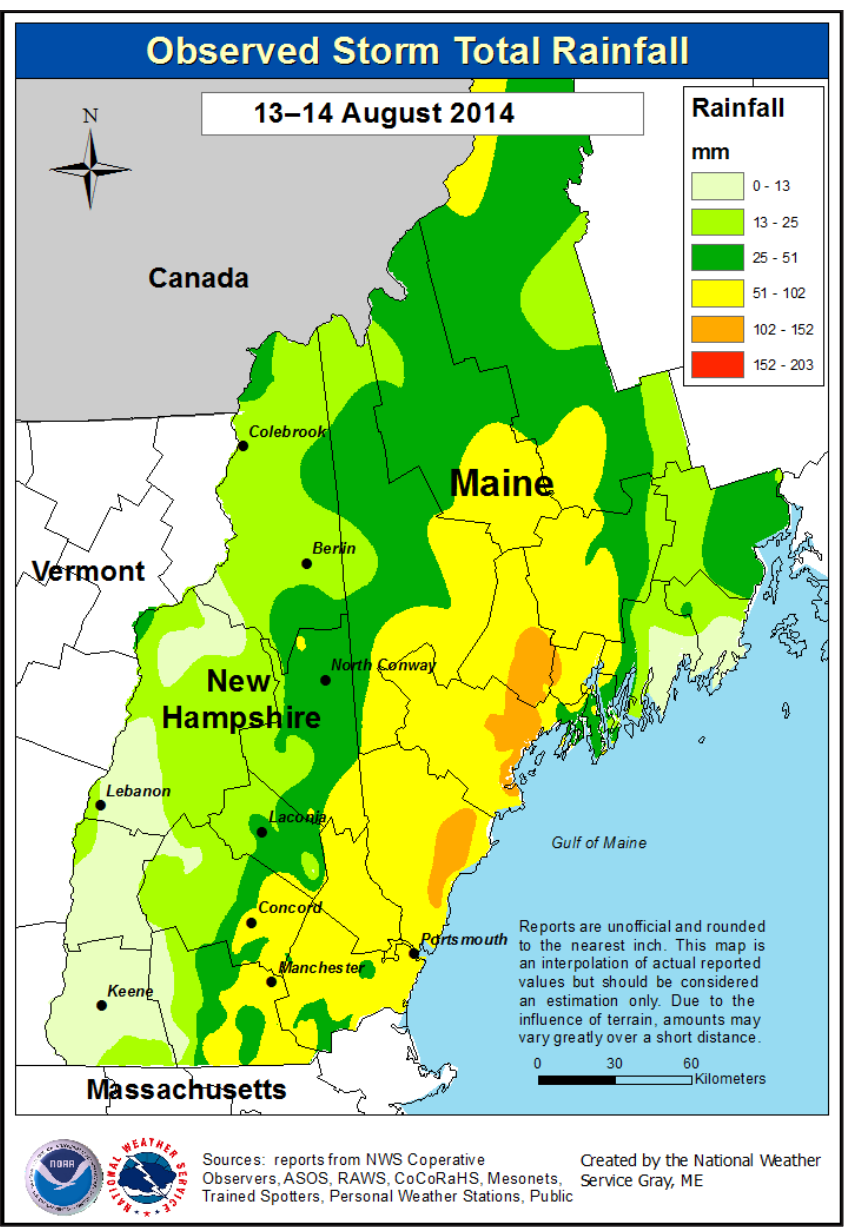

Figure 1. Observed 24-hr storm total precipitation reports over the NOAA/NWS Grey, Maine, county warning ending at 1200 UTC 14 August 2014 from Cooperative Observers, ASOS, CoCoRaHS Mesonets and trained spotters. Click image for an external version; this applies to all tables and figures hereafter.

often associated with heavy precipitation. Both back building and cell motion were found to be important factors in this case.

A variety of synoptic situations can lead to flash flooding. Maddox et al. (1979) identified a synoptictype flood event characterized by a strong low-level jet, a slow moving or quasi-stationary surface front, and an associated strong short-wave trough at $500 \mathrm{hPa}$. This model will be compared to the current case.

One unique characteristic of this event was the presence of a coastal front. The coastal front was first identified by Bosart et al. (1972). This mesoscale boundary between relatively warm maritime air and cooler inland air usually forms about 12 hours in advance of the passage of a low pressure center, and is manifested by a sharp temperature gradient and wind

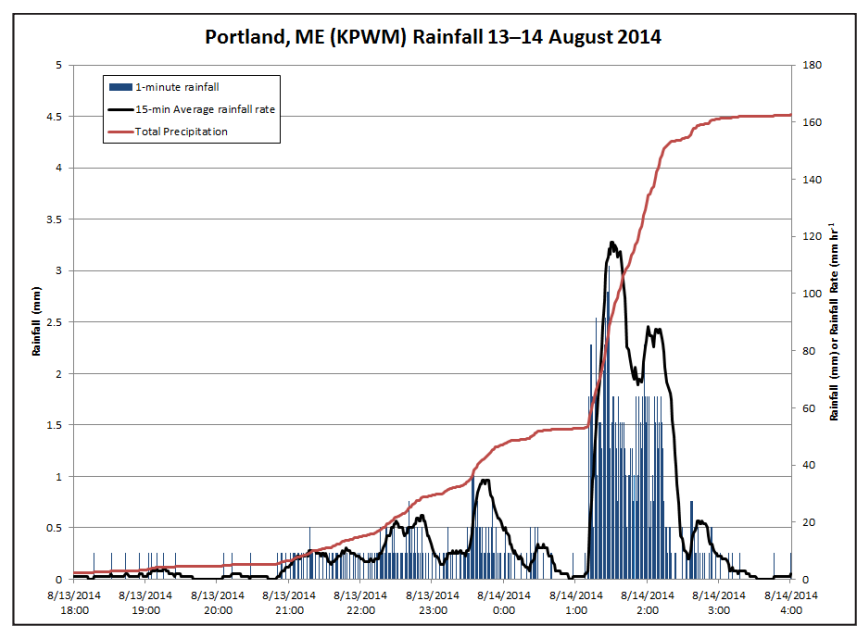

Figure 2. 1-min precipitation data from the Portland, ME ASOS (blue, mm), 15-min average rainfall rate (black, $\mathrm{mm} \mathrm{hr}{ }^{-1}$ ), and total accumulated precipitation (red, $\mathrm{mm}$ ).

shift. A coastal front classically results in the band of heaviest precipitation located just on the cold side of the front (Marks and Austin 1979). A coastal front can produce vertical velocities of near $2.5 \mathrm{~m} \mathrm{~s}^{-1}$ (Nielsen and Neilley 1990). As will be discussed, strong vertical velocities, when combined with high specific humidity, contributed to drive the historic rainfall in Portland.

This study examines the synoptic precursors and signals leading up to this heavy rain event and investigates the role of the coastal front in intensifying rainfall in the Portland area. This event had several unique characteristics, and unlike the other top five rainfall events at Portland, was not associated with a tropical system. In fact, despite occurring in midAugust, a coastal front, a phenomenon more commonly associated with winter precipitation events, was present.

\section{Data}

A variety of rainfall observations were used for this study. 1-min rainfall data came from the Portland ASOS (NOAA 1998). For the entire event, 24-hr total rainfall amounts were combined from all available surface observations including Community Collaborative Rain, Hail and Snow Network (CoCoRaHS) observers (Cifelli et al. 2005), National Weather Service Cooperative Observer Program (COOP) Observations, and additional ASOS instrumentation throughout the region. The KGYX WSR-88D storm total rainfall data (Fulton et al. 1998) were used to examine the areal coverage of the heavy rain. The North American Regional Reanalysis (NARR) (Mesinger et al. 2006) 
and Rapid Refresh (RAP13) analysis (Benjamin et al 2016) were used to examine synoptic and mesoscale features.

\section{Analysis \\ a. Synoptic overview}

One of the contributors to the heavy rainfall was a synoptic-scale low pressure system tracking northeast along the Eastern Seaboard. There was a $1004 \mathrm{hPa}$ low center over Massachusetts at 0000 UTC 14 August 2014, with a trough extending northwest to southern Quebec. Even though a $1004 \mathrm{hPa}$ low is not generally considered a strong system, it is anomalous for midAugust. The standardized anomaly in the sea level pressure field was 2 to 3 standard deviations below the mean, with a recurrence interval of once every 5 to 10 years, highlighting to forecasters the rarity of this oncoming event (Graham and Grumm 2010). The synoptic scale low pressure created a broad region of upward motion over southern Maine. There was a broad area of upward vertical motion analyzed in the NARR, with a peak value of $1.5 \mathrm{~Pa} \mathrm{~s}^{-1}$ over the Portland area, satisfying one of the favorable ingredients for heavy rainfall identified by Doswell et al. (1996).

In addition to a relatively strong low pressure system, high specific humidity (q), was also present. Figure 3 shows the specific humidity at several levels at 0000 UTC 14 August 2014, the time of the heaviest precipitation at Portland. The specific humidity was one to two standard deviations above the average throughout all vertical levels.

The 0000 UTC 14 August 2014 sounding from Gray, Maine (KGYX, Fig. 4) highlights several additional aspects conducive to heavy rainfall. The lowest $5 \mathrm{~km}$ of the sounding was above freezing and completely saturated, providing a perfect environment for warm rain (collision-coalescence) dominated processes. This helped improve the precipitation efficiency contributing to the heavy rainfall (Davis 2001). The sounding had $47.41 \mathrm{~mm}$ (1.86 in) of precipitable water, which is above the 90th percentile of KGYX soundings for the date. Both the significant deep warm cloud layer and the amount of moisture contributed to the heavy rainfall.

Maddox et al. (1979) identified a synoptic type flood event characterized by a strong low-level jet parallel to a surface front, and an associated strong short-wave trough at $500 \mathrm{hPa}$. Figure 5 depicts the NARR analysis during this flood event. A $500 \mathrm{hPa}$ short-wave trough was digging into the Northeast United States. The area on the downstream anti-cyclonic side would be favored for flash flooding and indeed encompasses the record setting flood at Portland. To further focus the attention into Portland at the synoptic scale, a clear $850 \mathrm{hPa}$ jet maxima is oriented perpendicular to the coast. Thus, many of the ingredients identified by Maddox et al. (1979) were present for this event.

\section{b. Storm motion}

The prior section demonstrated the synoptic situation was ripe for a flood event. An anomalous low pressure system was aiding in transporting very moist air northward into the region, yielding significant moisture and upward motion necessary for heavy rainfall. The second component of heavy rainfall is event duration. The duration of events can be enhanced by back building. Jessup and Colucci (2012) identified several types of back building events associated with heavy rainfall in the Northeast United States. This case may be best characterized as being one in which a linear feature was followed by back-building convection.

A linear convective system or squall line was present over western Maine at 0100 UTC 14 August 2014 (Fig. 6). While the line's motion was from west to east, individual cells within the line moved from south to north, with average $0-6 \mathrm{~km}$ storm motion of $180^{\circ}$ at $14.9 \mathrm{~m} \mathrm{~s}^{-1}$ (29 kt) (Calculated using the 30R75 method of Maddox 1976, based on the 0000 KGYX 14 August 2014 sounding). To determine the rate of propagation, the mesobeta-scale convective elements (MBE) vectors $\left(\mathrm{V}_{\mathrm{MBE}}\right)$ for this system were calculated according to Corfidi et al. (1996).

As the system leaves New Hampshire there is little to no low-level jet present with the $850 \mathrm{hPa}$ flow on the RAP13 analysis from $160^{\circ}$ at only $10.2 \mathrm{~m} \mathrm{~s}^{-1}$ (20 kt) (Fig. 7). With a system motion from west to east and the $0-6$ $\mathrm{km}$ storm motion vector of $180^{\circ}$ at $14.9 \mathrm{~m} \mathrm{~s}^{-1}$ (29 kt), we see the orientation of the system's cold pool and gust front are perpendicular to the system motion resulting in a downwind propagation scenario. Following Corfidi (2003) and combining the upwind propagation vector with the mean $300-800 \mathrm{hPa}$ wind, this results in a $\mathrm{V}_{\mathrm{MBE}}$ of $180^{\circ}$ at $23.2 \mathrm{~m} \mathrm{~s}^{-1}(45 \mathrm{kt})$. MBEs within the line are racing quickly to the north, but despite extremely high rainfall rates, no significant flooding is reported.

When the squall line approached Portland, it encountered a very strong low-level jet and a coastal front that both impact system motion. Consider the dynamics of the system, which prior to arrival in Portland had been a strongly forward propagating 


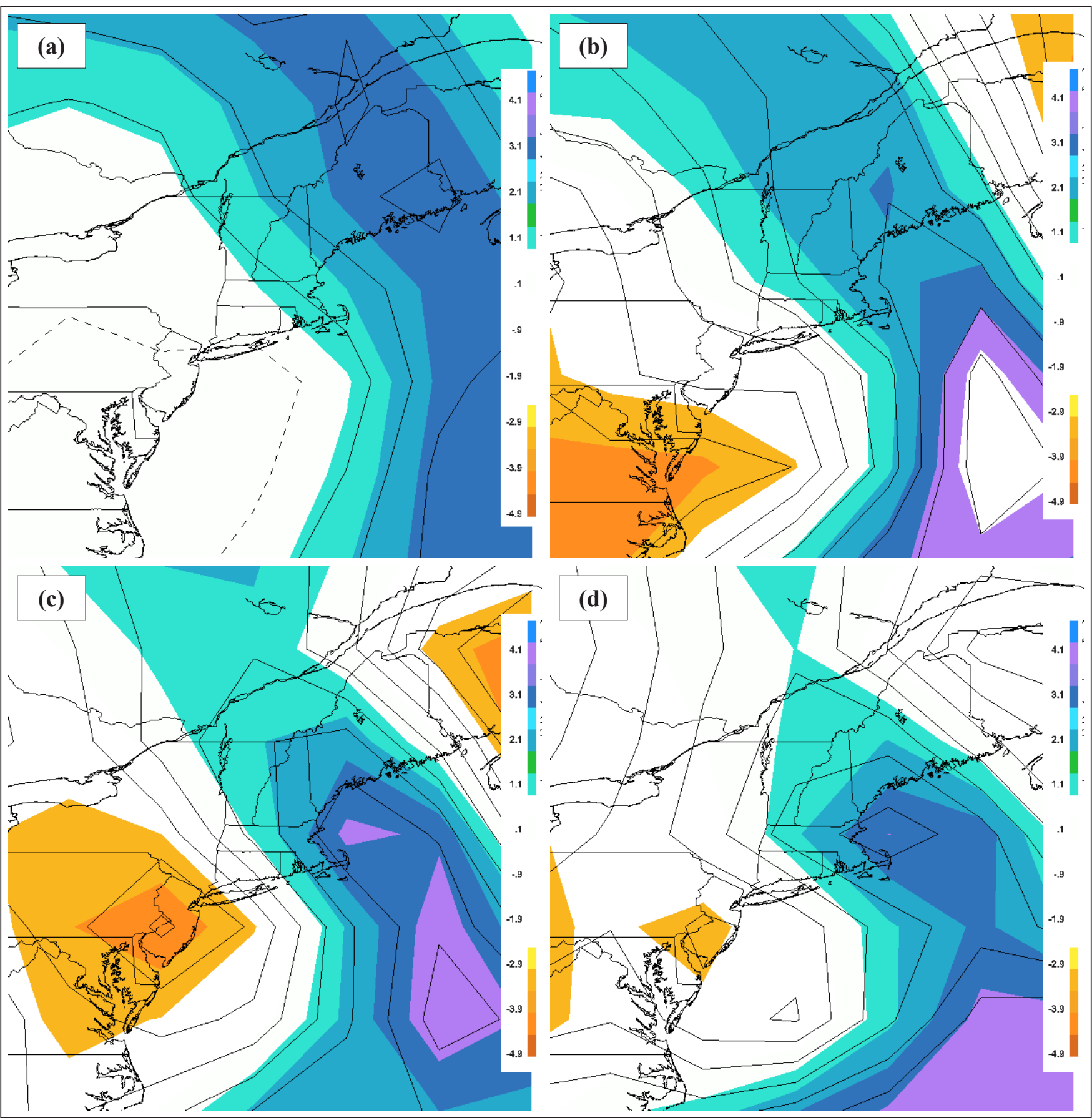

Figure 3. Specific humidity, q, (black lines, $\mathrm{g} \mathrm{kg}^{-1}$ ) and anomaly (shaded, $\mathrm{g} \mathrm{kg}^{-1}$ ) at $0000 \mathrm{UTC} 14$ August 2014, for (a) $500 \mathrm{hPa}$ (b) $700 \mathrm{hPa}$ (c) $850 \mathrm{hPa}$ (d) $925 \mathrm{hPa}$ from the NARR.

MCS. The motion of the convective line is governed by advection and propagation components (Corfidi 2003). The propagation component is influenced by the motion of the cold pool and the strength of the lowlevel jet, both of which change as the system moves into Portland.

The motion of a squall line is dependent, in part, on the system's cold pool and associated gust front. In this case it appears a coastal front (or, more properly, the cool-air dome to its north) augmented the system cold pool to create an enlarged, and much elongated, effective cold pool than previously was present. More importantly than the size of the cold pool/coastal front, the orientation of the coastal front (approx. $240^{\circ}$ to $60^{\circ}$ ) meant the system's effective cold pool was no longer perpendicular to the mean wind but now had 


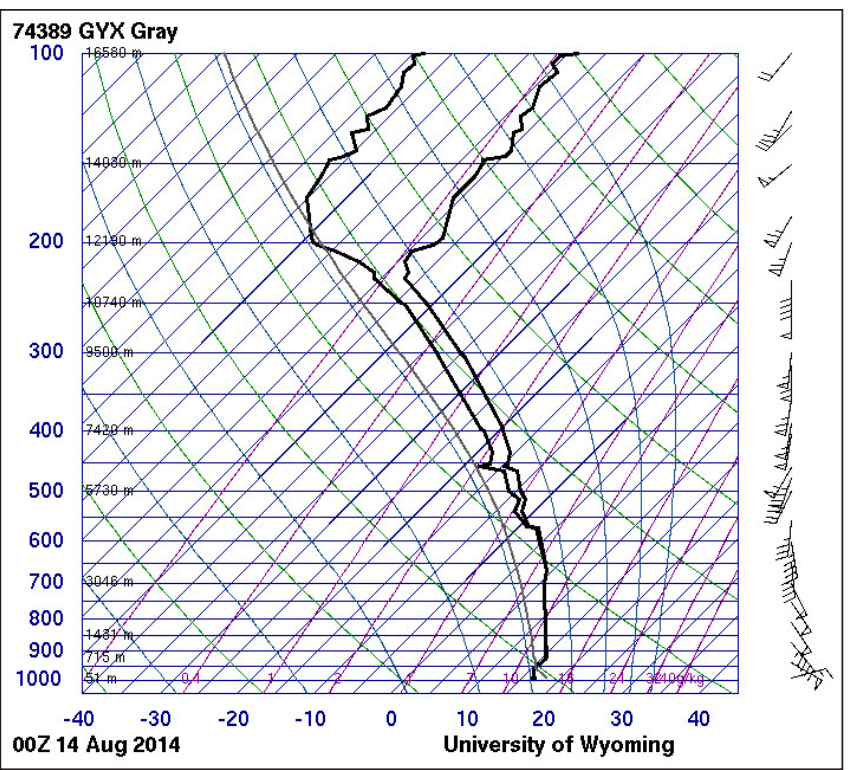

Figure 4. Sounding from Gray, ME for 0000 UTC 14 August 2014 (wind barbs, kt).

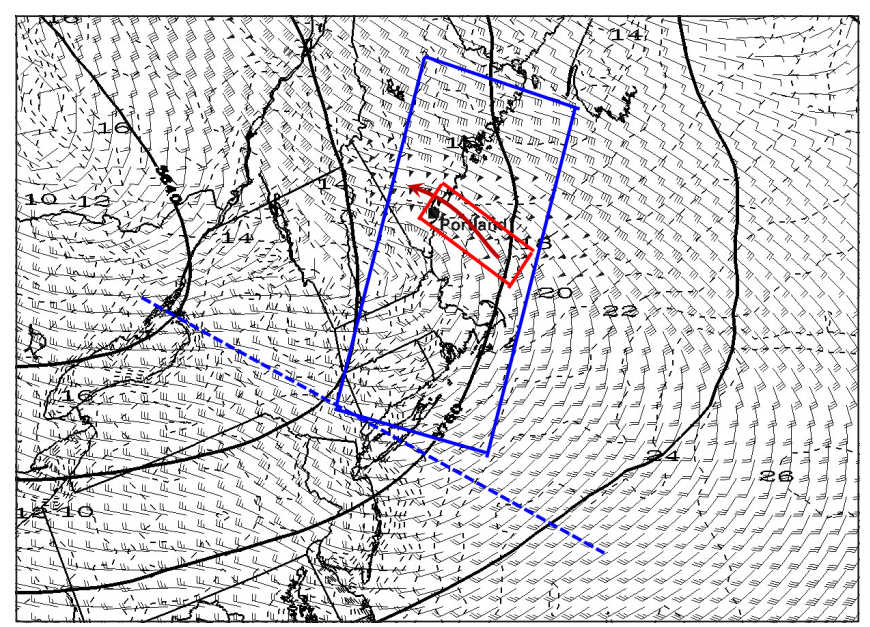

Figure 5. 0000 UTC 14 August 2014 North American Regional Reanalysis data showing $500 \mathrm{hPa}$ height (bold solid), $850 \mathrm{hPa}$ wind (kt, wind barbs), surface dewpoint $\left({ }^{\circ} \mathrm{C}\right.$, dashed lines). Area favorable for flash flood formation based on Maddox et al. (1979) includes downstream from $500 \mathrm{hPa}$ trough axis (blue dashed line) in proximity to $850 \mathrm{hPa}$ wind maxima (red arrow).

a component parallel to the mean wind, resulting in a back-building system. Further, the coastal front provided a more extensive source of enhanced lowlevel convergence than the system's cold pool alone.

Having established the system was back-building as it entered the Portland area, the methods of Corfidi et al. (1996) for backward-propagating systems can now be utilized to determine the propagation calculated by subtracting the $850 \mathrm{hPa}$ low-level jet from the mean

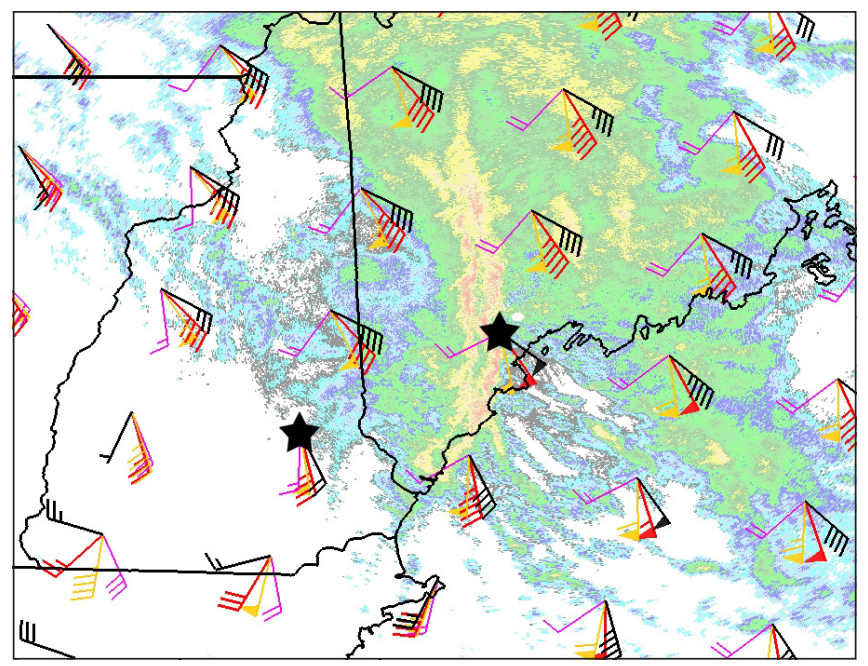

Figure 6. KGYX reflectivity $0.5^{\circ}$ tilt and RAP13 analysis of 300-800 hPa mean wind (red) and $850 \mathrm{hPa}$ flow (black, kt), upwind MBE motion (pink, kt) and downwind MBE motion (yellow, kt) for 0100 UTC 14 August 2014, when the system crossed Portland, Maine. Locations of the close-up in Fig. 7 indicated by stars.

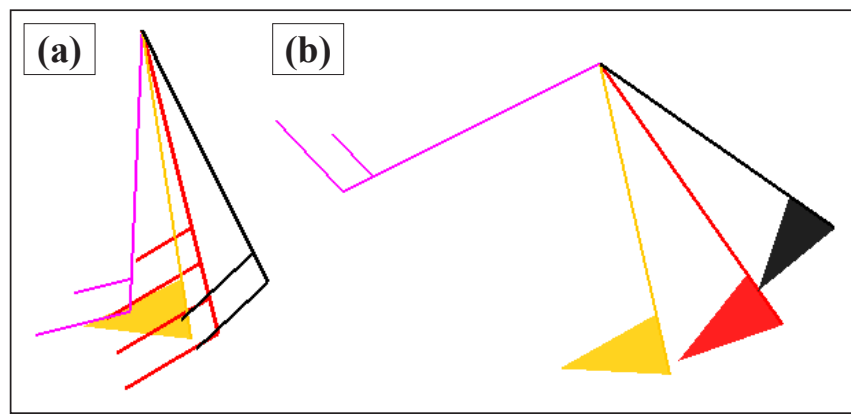

Figure 7. RAP13 analysis of 300-800 hPa mean wind (red) and $850 \mathrm{hPa}$ flow (black), upwind MBE motion (pink) and downwind MBE motion (yellow) for 0100 UTC 14 August 2014 for New Hampshire (a), and Portland, Maine, (b). Locations are indicated in Fig. 6.

storm motion. Prior to line's approach, storm motion derived from the $00 \mathrm{Z} \mathrm{KGYX} \mathrm{sounding} \mathrm{was} 180^{\circ}$ at 14.9 $\mathrm{m} \mathrm{s}^{-1}$ (29 kt); however, the $850 \mathrm{hPa}$ jet increased to $25 \mathrm{~m}$ $\mathrm{s}^{-1}(49 \mathrm{kt})$ from $135^{\circ}$, at Portland, giving an $V_{M B E}$ of $280^{\circ}$ at $18.5 \mathrm{~m} \mathrm{~s}^{-1}(36 \mathrm{kt})$. The change in the direction and increase in speed of the low-level jet resulted in system propagation evolving to one exhibiting an increasing degree of backward or upstream development, rather than the mainly forward propagation seen prior to the entrance into the low-level jet.

Because sounding data was not available across the region, RAP13 analysis is used to examine the spatial variability in the $V_{M B E}$. The spatial changes in the low- 
level jet play a significant role in enhancing the backbuilding by changing the magnitude and direction of $V_{M B E}$. Consider the spatial variability of the low-level jet and $V_{M B E}$ from RAP13 shown in Fig. 6. While the forward propagation vector (yellow) remains largely out of the south for the entire region, the backwards propagation vector (pink) turns from being southerly and perpendicular to the line motion in New Hampshire to partially parallel to the line motion in Portland (Fig. 7). Throughout the region, the magnitude of $V_{M B E}$ remains similar at 7.7-10 $\mathrm{m} \mathrm{s}^{-1}(15-20 \mathrm{kt})$ for backward propagation, and around $25 \mathrm{~m} \mathrm{~s}^{-1}(50 \mathrm{kt})$ for forward propagation. Normally, a large-magnitude $V_{M B E}$ is associated with fast-moving systems and no flooding. However, in this case, the change from forward to backward propagation and the accompanying change in the direction of $V_{M B E}$ - and not just $V_{M B E}$ magnitude - are important in determining the predominant threat (excessive rainfall) posed by the MCS.

Examining the motion of the convective line as a whole, as determined from timing the leading edge of the precipitation echoes from the KGYX radar, the line moved from $270^{\circ}$ at $10.8 \mathrm{~m} \mathrm{~s}^{-1}(21 \mathrm{kt})$. Taking this motion into account we can see the effect of the changing $V_{M B E}$. As the line enters the region where the low-level jet is the strongest, the direction of the MBE motion changes from perpendicular to the line motion to partially parallel to the line motion. This has the effect of increasing the length of time individual cells remain over the region, providing for the second component of heavy rain - a relatively long duration compared to when the system was moving through New Hampshire.

The impacts of spatial variability of MBE motion seen in the RAP13 analysis of this event in Fig. 6, can be idealized. Consider the schematic in Fig. 8. In scenario (a), what was seen initially in New Hampshire, timing the leading edge of the precipitation echo shows the convective line is moving from the west and the MBEs are moving from the south twice as fast. As time progresses, only one $\mathrm{MBE}$, (denoted ' $\mathrm{A}$ ' in the figure) is able to pass over the point of interest, $X$. In scenario (b) the line encounters the low-level jet near Portland. The line movement remains the same, but owing to the presence of the enhanced low-level jet, $V_{M B E}$ becomes west-southwest. The means the MBE motion is now partially parallel to the line motion, which sets up a scenario for training. In scenario (b) MBEs A, B and C are able to pass over point $\mathrm{X}$. Typically long residence times of individual MBEs over a region are associated with very slow $V_{M B E}$. However, this case demonstrates the importance of the orientation of $V_{M B E}$ relative to the

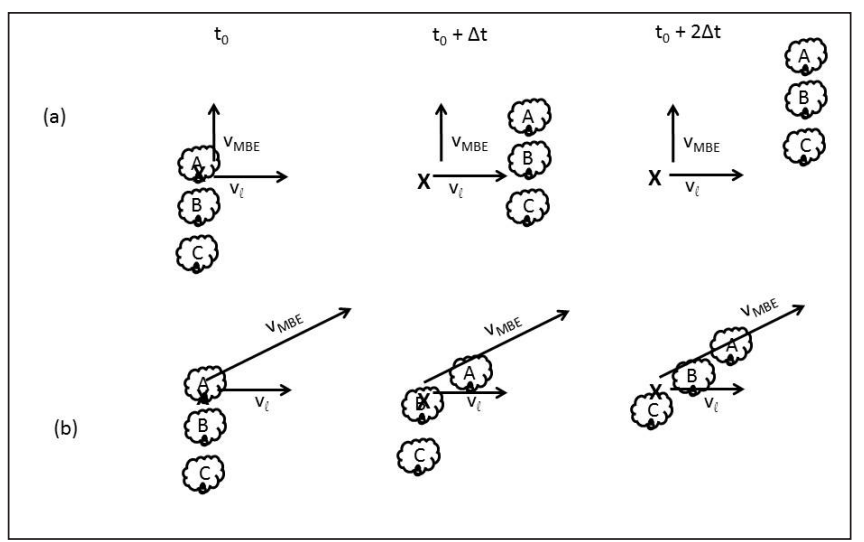

Figure 8. Effect of changing the orientation of the Mesoscale Beta element vector $\left(V_{M B E}\right)$ and convective line motion $\left(V_{l}\right)$ for a series of convective MBEs (A, $\mathrm{B}, \mathrm{C})$ passing over location (X). In (a) $V_{M B E}$ and $V_{l}$ are perpendicular, resulting in only cell A passing over location X. In (b) $V_{M B E}$ has a component parallel to $V_{l}$ resulting in the line changing its orientation and cells $\mathrm{A}$, $\mathrm{B}$, and $\mathrm{C}$ all passing over location $\mathrm{X}$.

system motion. While the magnitude of $V_{M B E}$ remains fairly large, the orientation of the $V_{M B E}$ to the convective line motion results in a long residence time.

The concept of residence time for any convective system can be formulated more generally. For any system with velocity $\mathrm{V}_{1}$ and an environment with $V_{M B E}$, the increase in time spent over a region because of a decrease in the angle between the line motion and the MBE motion, can be expressed via the component of the $V_{M B E}$ parallel to the line motion $\left(\operatorname{proj} V_{1} V_{M B E}\right.$ ) as compared to the line motion, proposed as the "residence factor' $\left(t_{R}\right)$ and expressed as:

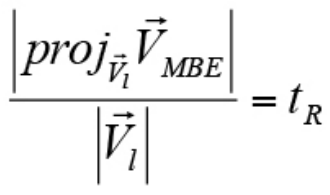

For this case, the line motion is $270^{\circ}$ at $21 \mathrm{kt}$, giving $t_{R}$ of 1.6 as the increase in time because of the altered orientation. Thus, Portland experienced high rainfall rates for over 2 times longer $\left(1+t_{R}\right)$ than any preceding location the line passed because of the changes in $\mathrm{MBE}$ direction upon entering the low-level jet.

\section{c. The coastal front}

Thus far, it has been demonstrated that high specific humidity, high precipitation efficiency, and the potential for long duration and back building convection contributed to the formation of heavy rain. 
The final major ingredient required to produce heavy rain is upward motion. In this case, upward motion was maximized by the presence of a coastal front.

New England coastal fronts may be formed in several ways. Once such area favorable to coastal front formation is "...beneath the forward side of advancing troughs...near mountain barriers where upslope flow results in differential airmass cooling and stabilization..." (American Meteorological Society 2015). In this case Fig. 5 shows the $500 \mathrm{hPa}$ height field, with the area around Portland in the favored region for coastal front formation ahead of an advancing upper level trough.

Following the calculation method of Nielsen (1989) the potential for frontogenetical forcing to be generated by the presence of warm advection in a rotating stratified flow past orography is considered (Gardner 1986). Table 1 lists the relevant parameters for the lowest layer observed in the Gray, ME sounding from 000014 August 2014. Overall the lowest warm advection layer was found to have Froude number (Fr) 1.2 and Rossby number (Ro) 3.33, falling within the 1 $\leq \mathrm{Fr} \leq 1.5$ and $\mathrm{Ro} \geq 2$ range identified as characteristic of orographic blocking enhancing frontogenesis in New England. Thus, the environment favored not only synoptic signals for heavy rainfall, but also coastal front formation.

A coastal front formed ahead of the low pressure center. Figure 9 shows the location at 2200 UTC 13 August 2014. The front extends from eastern Massachusetts northeastward across coastal Maine. The inland location of this front along with the orographic blocking parameters characterize it as a type-C coastal front (Nielsen 1989); in these cases coastal frontogenesis is found to take place away from the coast with minimal land-sea differences. At 2200 UTC 14 August 2014 the air temperatures along the coastal plain were around $17^{\circ} \mathrm{C}\left(63^{\circ} \mathrm{F}\right)$, while the water temperature at 44007 buoy (19 km southeast of Portland Jetport approximately 5 $\mathrm{km}$ offshore) was $16.6^{\circ} \mathrm{C}$ (62 F), yielding almost no land sea contrast.

The main role of the coastal front is to provide the upward vertical motion necessary to sustain the high rainfall rates. Figure 10 shows a radial velocity cross section of the coastal front near Portland taken from the KGYX radar just before the convective line of precipitation moved into the area. From this cross section we can identify the frontal slope as the zone of convergent winds indicated from the radar. The convergence is shown in Fig. 10 as the junction of the outbound velocity (red) and inbound velocity (green)
Table 1. Blocking parameters computed for the KGYX 0000 UTC 14 August 2014 sounding. U is positive towards 300 degrees, and $\mathrm{V}$ is positive towards 30 degrees.

\begin{tabular}{|l|l||}
\hline Variable & Surface-961 hPa \\
\hline$U$ & $11.6 \mathrm{~m} \mathrm{~s}^{-1}$ \\
\hline$\Delta v / 500{\mathrm{~m}\left(\mathrm{~m} \mathrm{~s}^{-1}\right)}^{-1} 4.8 \mathrm{~m} \mathrm{~s}^{-1}$ \\
\hline$\Delta \theta_{w} / 500 \mathrm{~m}$ & $2.8 \mathrm{~K}$ \\
\hline$F r$ & 1.18 \\
\hline$R_{o}$ & 3.33 \\
\hline
\end{tabular}

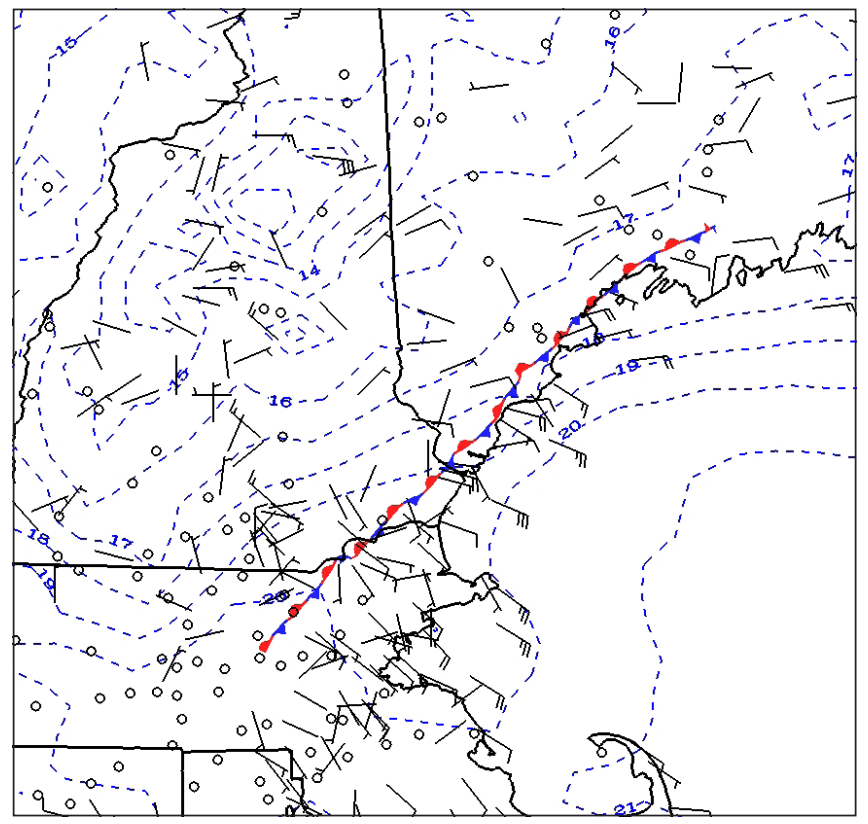

Figure 9. 2200 UTC 13 August 2014 surface wind observations (kt, wind barb) from mesonet, airport, and marine locations, and isotherms (blue, dashed) from RAP analysis. The approximate location of the coastal front across New England is indicated.

beginning at the surface just northwest of Portland and extending upward and inland toward North Windham. This frontal surface extends $1.5 \mathrm{~km}$ aloft over a distance of approximately $16 \mathrm{~km}$, giving a slope of $5.3^{\circ}$. The flow up and along the frontal surface is $\sim 25 \mathrm{~m} \mathrm{~s}^{-1}$, yielding 
an estimated upward velocity component of $2.4 \mathrm{~m} \mathrm{~s}^{-1}$. d. Heavy rainfall

Rainfall rates are directly proportional to the upward velocity and the specific humidity (Doswell et al. 1996). In this case, upward velocity was created by both synoptic scale rising motion and the coastal front. In the vicinity of the coastal front, the $2.4 \mathrm{~m} \mathrm{~s}^{-1}$ upward motion associated with the boundary, along with $1.5 \mathrm{~m}$ $\mathrm{s}^{-1}$ ascent provided by the synoptic-scale pattern and the $12 \mathrm{~g} \mathrm{~kg}^{-1}$ mixing ratio air at $925 \mathrm{hPa}$, can be used to determine the potential precipitation rate $(\mathrm{P})$. The precipitation rate is proportional to the Precipitation efficiency (E), specific humidity (q), and upward motion (w). (Doswell et al. 1996)

$$
P=E q w
$$

Assuming an idealized precipitation efficiency of 1 yielded potential precipitation rates in excess of $200 \mathrm{~mm}$ $\mathrm{hr}^{-1}$. Without the coastal front's contribution of $2.4 \mathrm{~m}$ $\mathrm{s}^{-1}$ upward motion, the resulting rainfall rates would be expected to be third as much. Examining the observed precipitation recorded at the Portland ASOS (Fig. 2), we see the peak in rainfall rates was approximately $110 \mathrm{~mm}$ $\mathrm{hr}^{-1}$, supporting the conclusion the costal front's upward motion would be needed to produce the magnitude of heavy rainfall observed.

Further support for the role of the coastal front in the heavy rainfall can been seen in the spatial distribution of the rainfall. Radially extending minima in precipitation are present because of beam blockage at the KGYX radar. In general however, moving inland from the coastal front (northwest), the storm total precipitation from the KGYX radar (Fig. 11) decreased. The observed radar velocities along the front also decrease in tandem with the precipitation amounts. Thus, the coastal front appears to have significantly augmented upward motion and, therefore, contributed to the precipitation maximum over Portland.

\section{Conclusions}

The historic urban flash flooding of 14 August 2014 at Portland, ME serves to exemplify several environmental signals for flash flooding to which forecasters should be attuned: (1) an abnormally high specific humidity was transported into the region yielding ample available moisture. (2) A low-level jet maximum downstream of an upper level short-wave trough increased moisture transport. (3) Wind fields

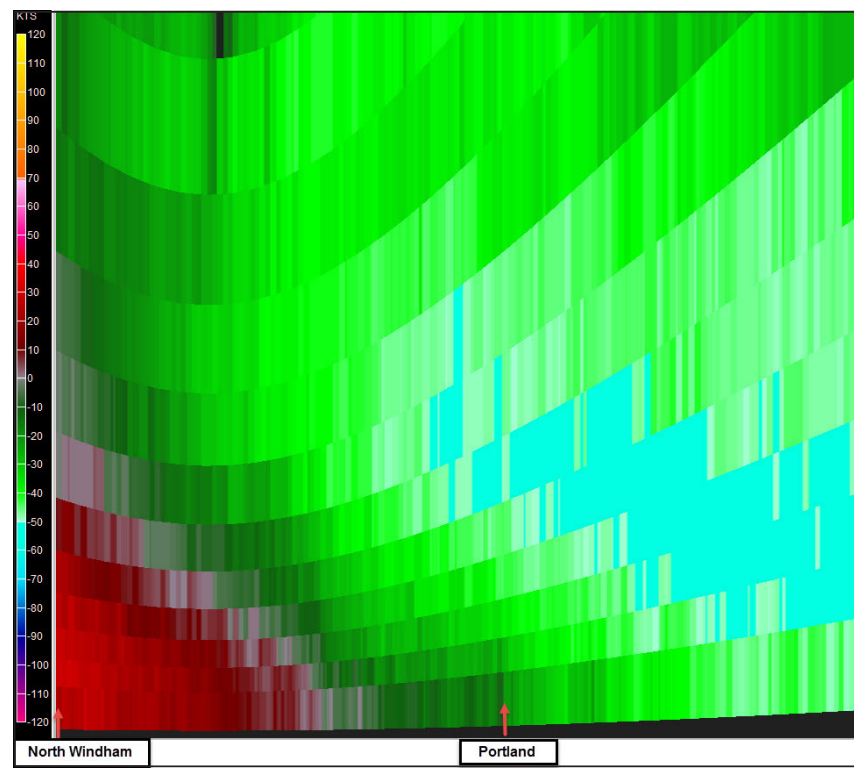

Figure 10. $50 \mathrm{~km}(32 \mathrm{mi})$ velocity data (kt, colored) cross section perpendicular to the coastal front at Portland, Maine, 0000 UTC 14 August 2014 from KGYX velocity data. Vertical scale is $3.05 \mathrm{~km}$ (10 000 $\mathrm{ft})$. The location of the cross-section is noted in Fig. 11.

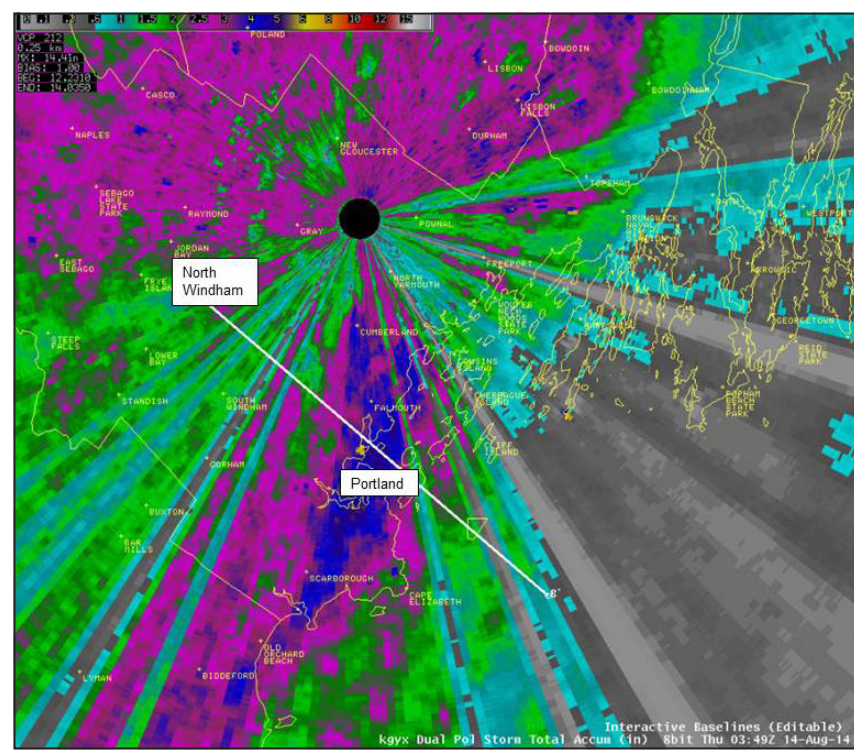

Figure 11. Storm total precipitation from KGYX. The maximum in observed storm total precipitation occurs directly over Portland, Maine. The location of the cross section in Fig. 10 is noted by the white line.

favored the formation of back building storms, which increased the duration of the precipitation. (4) Warm rain processes were present. (5) The orientation of the line motion and MBE motion $\left(\mathrm{V}_{\mathrm{MBE}}\right)$ resulted in increased residence time over one location.

In addition to these classical heavy rain signatures, 
the environment favored coastal front formation, with vertical wind profiles promoting blocking characteristics and the synoptic pattern supporting low-level frontogenesis. The presence of a coastal front served to increase upward motion, focusing the heaviest precipitation into a very narrow region. The coastal front provided a unique focus to the rainfall in this case, and the existence of a coastal front should be considered, regardless of the time of year, when forecasting localized precipitation patterns.

Further, this case highlights the importance of considering the synoptic flow and direction of MBE motion and not just $\mathrm{V}_{\mathrm{MBE}}$ magnitude when assessing the risk for heavy rainfall. The concept of residence time as a function of the angle between the synoptic motion and $\mathrm{V}_{\mathrm{MBE}}$ is introduced. This residence time should be examined by forecasters to assess the potential for heavy rain attributable to changes in $\mathrm{V}_{\mathrm{MBE}}$ direction and system motion.

Acknowledgments. NARR Reanalysis data provided by the NOAA/OAR/ESRL PSD, Boulder, Colorado, USA. [Available online at: www.esrl.noaa.gov/psd/]

\section{REFERENCES}

American Meteorological Society, cited 2015: Coastal Front. Glossary of Meteorology. [Available online at glossary. ametsoc.org/wiki/Coastal front]

Benjamin, S. G. and Coauthors, 2016: A North American hourly assimilation and model forecast cycle: The Rapid Refresh. Mon. Wea. Rev., 144, 1669-1694, Crossref.

Bosart, L. F., C. J. Caudo, J. H. Helsdon Jr, 1972: Coastal frontogenesis. J. Appl. Meteor, 11, 1236-1258, Crossref.

Cifelli, R. and Coauthors, 2005: The Community Collaborative Rain, hail and Snow Network: informal education for scientists and citizens. Bull. Amer. Meteor. Soc., 86, 1069-1077, Crossref.

Corfidi, S. F., 2003: Cold Pools and MCS propagation: forecasting the motion of downwind-developing MCSs. Wea. Forecasting, 18, 997-1017, Crossref.

, J. H. Merritt, and J. M. Fritsch, 1996: Predicting the movement of mesoscale convective complexes. Wea. Forecasting, 11, 41-46, Crossref.

Davis, R. S., 2001: Flash flood forecast and detection methods. Severe Convective Storms, Meteor. Monogr. No. 50, Amer. Meteor. Soc., 481-525, Crossref.

Doswell, C. A., H. E. Brooks, and R. A. Maddox, 1996: Flash flood forecasting: an ingredients-based methodology. Wea. Forecasting, 11, 560-581, Crossref.
Fulton, R. A., J. P. Breidenbach, D-J. Seo, D. A. Miller, and T O'Bannon, 1998: The WSR-88D rainfall algorithm. Wea. Forecasting, 13, 377-395, Crossref.

Gardner, S. T. 1986: An orographic mechanism for rapid frontogenesis. Ph.D. thesis, Massachusetts Institute of Technology, Cambridge, MA, 222 pp. \{Available online at: hdl.handle.net/1721.1/52888].

Graham, R. A. and R. H. Grumm, 2010: Utilizing normalized anomalies to assess synoptic-scale weather events in the western United States. Wea. Forecasting, 25, 428445, Crossref.

Jessup, S. M. and S. J. Colucci, 2012: Organization of flashflood-producing precipitation in the Northeast United States. Wea. Forecasting, 27, 345-361, Crossref.

Maddox, R. A., 1976: An evaluation of tornado proximity wind and stability data. Mon. Wea. Rev., 104, 133-142, Crossref.

, C. F. Chappell, and L. R. Hoxit, 1979: Synoptic and meso- $\alpha$ aspects of flash flood events. Bull. Amer. Meteor. Soc., 60, 115-123, Crossref.

Marks, F. D., Jr., and P. M. Austin, 1979: Effects of the New England coastal front on the distribution of precipitation. Mon. Wea. Rev., 107, 53-67, Crossref.

Menne, M. J. and Coauthors, 2012: Global Historical Climatology Network - Daily (GHCN-Daily), Version 3. [daily rainfall]. NOAA National Climatic Data Center. doi:10.7289/V5D21VHZ [Accessed: 27 December 2014].

Mesinger, F. and Coauthors, 2006: North American Regional Reanalysis. Bull Amer Meteor. Soc. 87, 343-360, Crossref.

NCDC, 2014: Storm Data. 56, No 8, 414 pp. [Available online at: https://www.ncdc.noaa.gov/IPS/sd/sd.html]

Nielsen, J. W., 1989: The formation of New England coastal fronts. Mon. Wea. Rev., 117, 1380-1401, Crossref. , and P. P. Neilley, 1990: The Vertical Structure of New England Coastal Fronts. Mon. Wea. Rev., 118, 17931807, Crossref.

NOAA, 1998: Automated Surface Observing System (ASOS) User's Guide. [Available online at: www.nws.noaa.gov/ asos/aum-toc.pdf] 